DOI: $10.1515 /$ lpts-2016-0031

\title{
RESULTS OF THE ONGOING MONITORING OF THE POSITION OF A GEOSTATIONARYTELECOMMUNICATION SATELLITEBYTHEMETHOD OF SPATIALLY SEPARATED BASIS RECEIVING OF DIGITAL SATELLITE TELEVISION SIGNALS
}

\author{
F. Bushuev ${ }^{1}$, M. Kaliuzhnyi ${ }^{1}$, Y. Sybiryakova ${ }^{1}$, O. Shulga $^{1}$, S. Moskalenko ${ }^{2}$, \\ O. Balagura ${ }^{3}$, V. Kulishenko ${ }^{4}$ \\ 1 "Nikolaev Astronomical Observatory" Research Institute (RI NAO), \\ 1 Observatorna Str., Mykolaiv, 54030, UKRAINE \\ ${ }^{2}$ Western Centre of Radio Engineering Surveillance (WCRES), \\ Kosmonavtov Str., Mukachevo, 89612, UKRAINE \\ ${ }^{3}$ State Enterprise "Ukrkosmos", 9 Boryspilska Str., Kyiv, 02099, UKRAINE \\ ${ }^{4}$ Institute of Radio Astronomy of the National Academy of Sciences of Ukraine, \\ 4 Chervonopraporna Str., Kharkiv, 61002, UKRAINE
}

The results of the ongoing monitoring of the position of geostationary telecommunication satellite Eutelsat- $13 \mathrm{~B}\left(13^{\circ}\right.$ East $)$ are presented in the article. The results were obtained using a radio engineering complex (RC) of four stations receiving digital satellite television and a data processing centre. The stations are located in Kyiv, Mukachevo, Kharkiv and Mykolaiv.

The equipment of each station allows synchronous recording (by the GPS) of fragments of DVB-S signal from the quadrature detector output of the satellite television receiver. Samples of the complex signal are archived and sent to the data processing center through the Internet. Here three linearly independent slant range differences $(\Delta r)$ for three pairs of the stations are determined as a result of correlation processing of received signals. Every second measured values of $\Delta r$ are used to calculate Cartesian coordinates (XYZ) of the satellite in the coordinate system WGS84 by multilateration method.

The time series of $\Delta \mathrm{r}, X, Y$ and $Z$ obtained during continuous observations from March to May 2015 are presented in the article. Single-measurement errors of $\Delta \mathrm{r}, X, Y$ and $Z$ are equal to $2.6 \mathrm{~m}, 3540 \mathrm{~m}, 705 \mathrm{~m}$ and $455 \mathrm{~m}$, respectively. The complex is compared with known analogues. Ways of reduction of measurement errors of satellite coordinates are considered.

The radio engineering complex could be considered a prototype of a system of independent ongoing monitoring of the position of geostationary telecommunication satellites.

Keywords: Cartesian coordinates of geostationary satellites, DVB-S, radio interferometer. 


\section{INTRODUCTION}

The topicality of facility development of geostationary satellite (GEOS) ongoing monitoring is caused by the constant growth of population of the Earth geostationary zone. Continuous positioning of GEOS by terrestrial means is ensured only by radio engineering facilities. Optical observations are more accurate; hence, they are commonly used for calibration of radio engineering facilities. Errors of conventional optical devices are within $0.26 "-0.91$ " [1].

Radar tracking system, based on single station ranging and azimuth-elevation measurement, is the most common radio-engineering facility of positioning of geostationary satellites. Accuracy of $10^{\prime \prime}$ can be obtained by the system with an antenna of $10 \mathrm{~m}$ diameter at frequencies of $14 \mathrm{GHz}$, while accuracy of code ranging can be a few centimeters [2]. In the DARTS system (Digital Advanced Ranging with Transport-stream Signals), special ranging packets are inserted into the DVB-S (Digital Video Broadcasting-Satellite) transport stream and transmitted simultaneously with a payload [3]. The ranging accuracy of DARTS is $5 \mathrm{~cm}$.

The second remote radar is often used to increase the determination accuracy of the coordinates of the controlled geostationary satellite [4]. However, to determine more accurately the satellite azimuth measured by radar a radio interferometer is applied [4], [5]. The radio interferometer has two receivers of Ku-band downlink signals. Only 250 meters separate antennas of the receivers. This distance between the antennas allows for the appliance of a common local oscillator in the receivers. To reduce the phase distortion of the signals, RF signals are fed via cooled fiber optic lines from outputs of the antennas to inputs of mixers. The phase of the signal at the output of the receivers is determined by the discrete Fourier transform. The resulting value of phase difference is used to refine the azimuth of the satellite. The accuracy of phase difference determination is about $5 \%$ of a wavelength or $1.2 \mathrm{~mm}$ for a signal frequency of $13 \mathrm{GHz}$. The corresponding directional accuracy is about 1".

Chinese VLBI network (CVN) of four stations was used in the research [6] to calibrate the tracking system for geostationary satellites belonging to the COMPASS navigation system. Minimum baseline length of the CVN equals $1100 \mathrm{~km}$, and the maximum is $3250 \mathrm{~km}$. Signal transmitted by the geostationary satellites at a frequency of $2.2 \mathrm{GHz}$ was used as the VLBI beacon. Spectral width of the signal was approximately $2 \mathrm{MHz}$. The accuracy of delays measured by the VLBI was $3.6 \mathrm{~ns}$ and the accuracy of satellite coordinate determination was $10 \mathrm{~m}$.

A radio engineering complex $(\mathrm{RC})$ was developed at the Research Institute $\mathrm{NAO}$ for active geostationary telecommunication satellite positioning [7]. The basic principle of the $\mathrm{RC}$ is the determination of the difference of slant ranges to a satellite from a pair of receivers using the correlation analysis of the received DVB-S signals. Hence, the proposed approach is equivalent to that used in radio interferometry. The slant range difference to an observed radio source is also obtained there as a result of the correlation analysis of the received signals. The article presents the results of measurements of the coordinates of the geostationary satellite Eutelsat-13B. The results were obtained in the period from March to May 2015 using the upgraded RC. 


\section{RC: TECHNIQUE, HARDWARE AND SOFTWARE}

The Earth-centered Earth-fixed coordinate system is used to determine Cartesian coordinates of the tracked geostationary telecommunication satellite by the multilateration (or hyperbolic) method [8], [9]. Let $(x, y, z)$ and $\left(x_{i}, y_{i}, z_{i}\right)$ denote the desired satellite coordinates and the known coordinates of the $i$-th station, and let $R_{i}=\left[\left(x-x_{i}\right)^{2}+\left(y-y_{i}\right)^{2}+\left(z-z_{i}\right)^{2}\right]^{\frac{1}{2}}$ be the distance between the satellite and the $i$-th station. The following system of nonlinear equations can be used to find the satellite coordinates:

$$
R_{0}+\Delta r_{i}-R_{i}=0, i=1, \ldots, I-1
$$

where $\Delta r_{i}=c \cdot \Delta \tau_{i}$ - the difference between slant ranges obtained for the $i$-th and 0 -th stations;

$c-\quad$ the speed of light in vacuum;

$\Delta \tau_{i}-$ the difference between measured delays of the DVB-S signals received by the stations;

$I-\quad$ the number of spaced stations.

Hence, the complex should consist of four or more stations to determine three unknown satellite coordinates.

Initial values $\left(x^{0}, y^{0}, z^{0}\right)$ for the satellite coordinates are required for solving the nonlinear system of equations (1) using a numerical method. They should be defined in the same coordinate system as the coordinates of the stations. The coordinates of the stations are set in the Earth-fixed WGS84 (World Geodetic System of 1984) system because the WGS84 is the reference coordinate system used by the GPS and, therefore, the coordinates can be taken directly from the measurement data of GPS receivers used for synchronization of the stations [7]. The initial values $\left(x^{0}, y^{0}, z^{0}\right)$ can be computed with the following approximate geographical coordinates of the satellite relative to the WGS84 ellipsoid: $\varphi_{G S S}, \lambda_{G S S}=0$ и $h_{G S S}=36000 \mathrm{~km}$, where $\varphi_{G S S}, \lambda_{G S S}$ and $h_{G S S}$ denote the longitude, latitude and height of the geostationary satellite, respectively. Formulas for conversion between geographical and Cartesian coordinates may be found in [2], [10]. The given method of estimating $\left(x^{0}, y^{0}, z^{0}\right)$ allows one to solve the system of equations (1) in a few Newton's iterations.

Currently, the RC is composed of four $(I=4)$ identical stations receiving digital satellite TV (Digital Television-Satellite (DTV-S)), which are installed in the cities of Kyiv, Mukachevo, Mykolaiv and Kharkiv. The maximum distances between the stations are about $1000 \mathrm{~km}$ and $400 \mathrm{~km}$ along longitude and latitude, respectively.

Each station consists of:

1) The standard antenna-feeder system for the reception of DTV-S signals, with antennas of $0.9 \mathrm{~m}$ (in Kyiv, Mukachevo and Kharkiv) and $1.9 \mathrm{~m}$ (in Mykolaiv) in diameter;

2) DTV-S receiver (SkyStar1 or SkyStar2) performed as a PCI-card and upgraded in terms of outputting of in-phase and quadrature signals; 
3) Single-frequency ThunderBolt-E GPS receiver;

4) Digital USB-oscilloscope DSO5200A with $200 \mathrm{MHz}$ passband and 9-bit ADC (Analog Digital Converter);

5) Personal computer with USB and RS-232 ports, operable in Windows XP environment (1 GHz CPU clock rate; 1 Gb RAM, and 100 Gb HD capacity);

6) Internet connection at data rate of at least 80 Kbytes per second.

Detailed description of the station hardware and software is given in [7]. The hardware and software allow each station of the RC to record every second fragments of DTV-S complex signal synchronously with PPS (Pulse-Per-Second) signals incoming from the GPS receivers. A feature of USB-oscilloscopes DSO5200A employed as $\mathrm{ADC}$ is the dependence of the nominal sampling frequency $f_{n}$ on the duration $T_{s}$ of a recorded fragment:

$$
f_{n}=\frac{N_{s}}{T_{s}}
$$

where $N_{s}=10240$ - the constant equal to the size of sample. The value of $T_{s}$ depends on the selected scale of the oscilloscope. Two factors were taken into account in the research [7] to select the oscilloscope scale. First of all, Nyquist rate for recorded DVB-S signal was defined. Then the location of stations was chosen based on the obtained maximum value of $T_{s}$. Let $B$ denote the length of the baseline connecting the stations. The stations should be located so as to satisfy the inequality: $B \leq T_{s} \cdot c$. The restriction on the length of the baseline was significantly weakened by using the ability to change the PPS signal delay $\tau_{P P S}$ with respect to the beginning of a second. This ability is provided in the receivers ThunderBolt-E. The difference between delays of DTV-S signals received at two stations can be represented as the sum of two terms:

$$
\Delta \tau=\overline{\Delta \tau}+\hat{\tau}
$$

where $\overline{\Delta \tau}$ - the average difference of the delays, and $\hat{\tau}-$ the variation of the delay difference with respect to $\overline{\Delta \tau}$. The average difference of the delays $\overline{\Delta \tau}$ may be a few milliseconds because it depends on the length of the baseline connecting the stations and on the relative position of tracked satellite and baseline. The variation of the delay difference $\hat{\tau}$ depends on displacement of the satellite within its geostationary slot and it cannot exceed $20 \mu \mathrm{s}$. If there are several pairs of stations $\tau_{P P S}=0$ can be set for one (chosen) station. For the rest of the stations $\tau_{P P S}$ can be set equal to the value of $\overline{\Delta \tau}$ with respect to the chosen station. Numerical simulation may be used to estimate $\overline{\Delta \tau}$. The satellite orbital parameters required for the simulation could be found at the site: www.space-track.org. The DTV-S receivers employed in the RC can receive DVB-S signal at a symbol rate of 22000 or $27000 \mathrm{kSym} / \mathrm{s}$. The spectral width of the signals is about $30 \mathrm{MHz}$ [11]. Hence, their Nyquist rate is equal to $60 \mathrm{MHz}$. The value of $f_{n}$ closest to the Nyquist rate is $51.2 \mathrm{MHz}$. It corresponds to $T_{s}=200 \mu \mathrm{s}$ that is substantially greater than the possible values of $\hat{\tau}$. 
Every second complex samples of DTV-S signal are archived and sent through the Internet to the processing centre in Mykolaiv. Here the following is carried out for a given pair of stations [7]:

- Transforming the complex samples in real samples taking into account the structure of the DVB-S signal;

- Computing the correlation function of the real samples;

- Computing the difference of the delays of the DVB-S signals received by the stations.

The value of $\Delta \tau_{i}$ is estimated by the following formula:

$$
\Delta \tau_{i}=\left(\frac{n_{x i}}{k_{s r} \cdot f_{n}}+\tau_{P P S i}\right)-\left(\frac{n_{0}}{k_{s r} \cdot f_{n}}+\tau_{P P S 0}\right)-\Delta \tau_{h i} .
$$

Expression (2), unlike that used in [7], has a number of additional parameters: $\tau_{P P S i}$ and $\tau_{P P S 0}$ - given initial delays of PPS signals of GPS receivers of the stations; $\Delta \tau_{h i}$ - measured value of the difference of hardware delays of the stations;

$k_{s r}$ - measured coefficient of proportionality between a valid $\left(f_{v}\right)$ and nominal sampling frequencies:

$$
f_{v}=k_{s r} \cdot f_{n} .
$$

It is assumed that $\Delta \tau_{h i}$ depends on equipment characteristics of the stations (e.g., on the difference of the electrical lengths of cables between antennas and receivers and so forth), and $k_{s r}$ is the constant for the given type of USB-oscilloscope. The parameters $\Delta \tau_{h i}$ and $k_{s r}$ are determined during calibration before sending stations to their places of observation.

In (2), $n_{x i}$ and $n_{0}$ are measured in counts of the sampling frequency. The parameter $n_{x i}$ is equal to the offset of the maximum of the correlation function from the beginning of the sample obtained by the $i$-th station. The position of the maximum is confirmed using the Hilbert transform of the correlation function by the method proposed in [12]. Thus, in general, the value of $n_{x i}$ is a fractional non-negative value. The value of $n_{0}$ is also a non-negative value, but always it is integer because it equals to a given offset of the middle part of the sample obtained by the zero station. The offset is set from the beginning of the sample. The size of this middle part of the sample is always smaller than $N_{s}$, and it is equal to the sample size of correlator $\left(N_{c}\right)$. The parameters $n_{0}$ и $N_{c}$ are set so that variations of $\hat{\tau}$ with respect to $\left(\tau_{P P S i}-\tau_{P P S 0}\right)$ are within the interval $\left[\frac{-n_{0}}{f_{v}}, \frac{N_{s}-N_{c}-n_{0}}{f_{v}}\right]$.

Three linearly independent values of $\Delta \tau_{i}(i=1, . ., I-1)$ are computed using (2). Then they are used in (1) to find every second values of the Cartesian coordinates of the tracked satellite.

Additional software is used to estimate statistical characteristics of $\Delta r$ and ( $x$, $y, z)$. 


\section{OBSERVATION RESULTS}

Position of ongoing observations of geostationary satellite Eutelsat-13B presented in the article was obtained by the RC during the period from 11 March 2015 to 20 May 2015. Eutelsat-13B is co-located in an orbital slot of $13^{\circ}$ East with two other satellites, Eutelsat-13C and Eutelsat-13D. The DVB-S signal at the frequency of $11541 \mathrm{MHz}$ with vertical polarization and at the symbol rate of $22000 \mathrm{kHz}$ is received by the RC stations during the whole observation period, including the analysed interval. The duration of sample of recorded signals of quadrature detector is set to $T_{s}=200 \mu \mathrm{s}$. It corresponds to the nominal sampling rate $f_{n}=51.2 \mathrm{MHz}$ that is close to the Nyquist rate for the received signal. The PPS signal delays for the stations in Kyiv, Kharkiv and Mukachevo are set in such a way as to keep zero delay for the Mykolaiv station and are equal to $888 \mu \mathrm{s}, 1270 \mu \mathrm{s}$ and $-215 \mu \mathrm{s}$, respectively.

Differences of slant ranges changing over time are shown in Fig. 1 for the three pairs of the stations: Kharkiv-Mykolaiv, Mukachevo-Mykolaiv and Kyiv-Mykolaiv. The station in Mykolaiv is the zero station for all pairs listed in Fig. 1. As a result of the correlation analysis, the delays of the signals received in Kharkiv, Mukachevo and Kyiv are computed regarding the delay of the signal received in Mykolaiv. The $\mathrm{y}$-axis of the graphs represents the values of $\overline{\Delta r}$, which were obtained by averaging the every second samples of $\Delta r$ at the interval of 60 seconds. The $\mathrm{x}$-axis represents time (UTC) from 11 March 2015 to 20 May 2015.

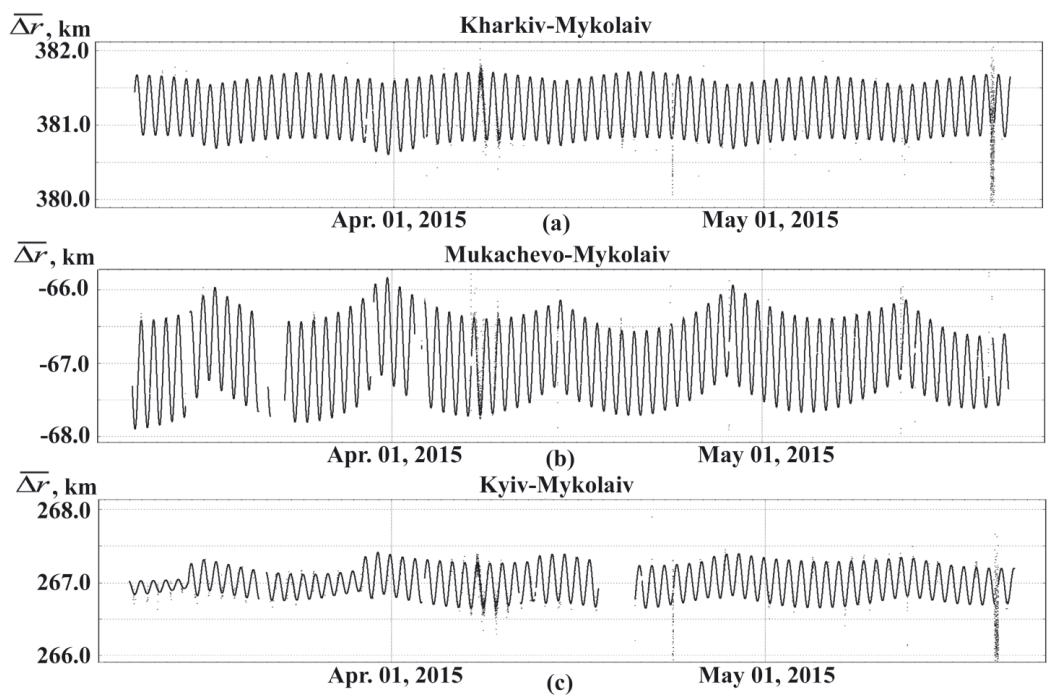

Fig. 1. Slant range differences for three pairs of stations: Kharkiv-Mykolaiv (a), Mukachevo-Mykolaiv (b) and Kyiv-Mykolaiv (c). Observation time is from 11 March 2015 to 20 May 2015.

It should be noted that there are a few specific intervals of abrupt changing in the amplitude of the diurnal variations of $\overline{\Delta r}$ on its graph obtained for the pair of the stations Kyiv-Mykolaiv (its baseline is oriented along latitude). Especially clearly these changes were evident in the intervals from 11 March 00:00 UTC to 15 March 16:28 UTC and from 15 March 16:28 UTC to 29 March 17:31 UTC. Obviously, the satellite orbit had been corrected on 15 March 16:28 UTC and 29 March 17:31 UTC. 
Empirical probability density $(P(\sigma=\xi))$ and distribution $(P(\sigma<\xi))$ functions of values of standard deviation (SD or $\sigma$ ) are given in Fig. 2. The values of $\sigma$ were computed at 60 -second intervals of time for each of the samples presented in Fig. 1.

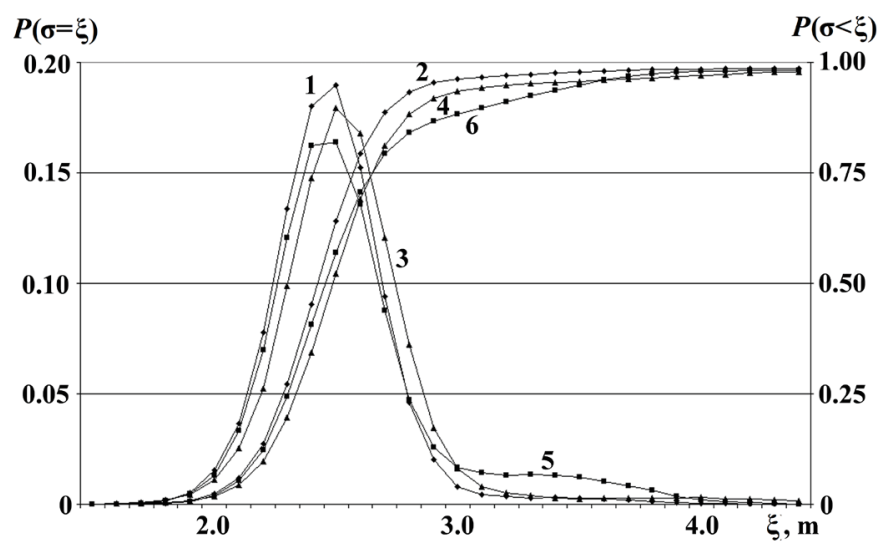

Fig. 2. Empirical probability density function (1,3 and 5) and distribution function (2, 4 and 6) of standard deviation of slant range differences for three pairs of stations: Kharkiv-Mykolaiv (1 and 2), Mukachevo-Mykolaiv (3 and 4) and Kyiv-Mykolaiv (5 and 6). Observation time from 11 March 2015 to 20 May 2015.

From the data given in Fig. 2 it follows that the median of the SD of $\Delta r$ equals $2.5 \mathrm{~m}$ for the pair of the stations Kharkiv-Mykolaiv and $2.6 \mathrm{~m}$ for the other two pairs. It should be noted that all the empirical distributions of $\sigma$ given in Fig. 2 are asymmetric with respect to the median values. All three graphs $P(\sigma=\xi)$ subside more slowly in the interval $(\xi>3.0)$ in comparison with the interval $(\xi<2.2)$. Graph 2 obtained for the pair Kyiv-Mykolaiv has a clearly pronounced local maximum in the range of $(\xi>3.0)$.

Every second values of Cartesian coordinates $(X, Y, Z)$ of Eutelsat-13B satellite are obtained in the WGS84 coordinate system by solving the system of nonlinear equations (1) for three values of DVB-S signal, relative delays measured by the RC. The corresponding graphs of averaging values of the coordinates $\bar{X}, \bar{Y}, \bar{Z}$ are given in Fig. 3. The averaging was performed in intervals of 60 seconds.

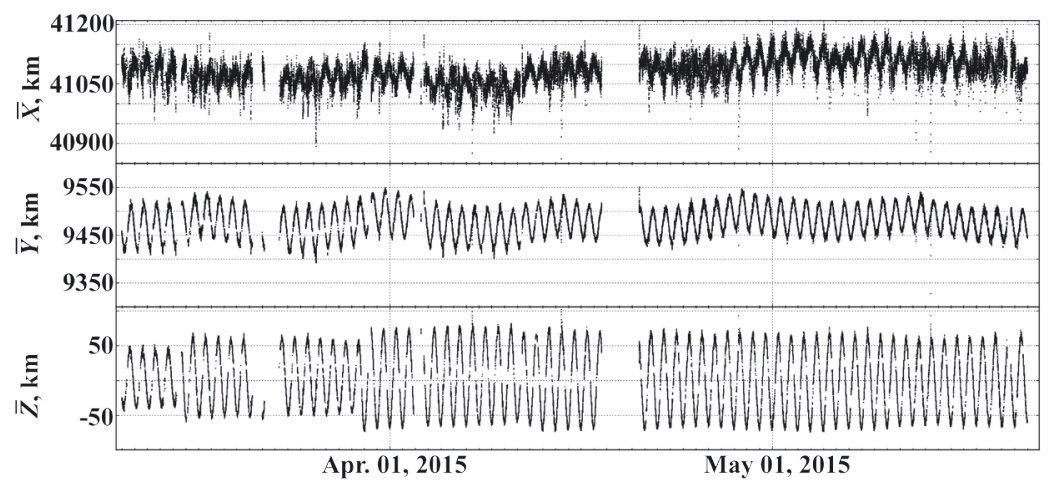

Fig. 3. Cartesian coordinates of Eutelsat-13B satellite in the WGS84. Observation time from 11 March 2015 to 20 May 2015. 
It should be noted that an abrupt change in the amplitude of diurnal variations of $\bar{Z}$ is clearly visible on its graph on 15 March 16:28 UTC and 29 March 17:31 UTC, as well as on the graph of $\overline{\Delta r}$ obtained for the pair of the stations Kyiv-Mykolaiv (Fig. 1). These changes may be associated with the satellite orbit corrections.

Spatial positions of the tracked satellite are shown in Fig. 4. It was built according to the data shown in Fig. 3.

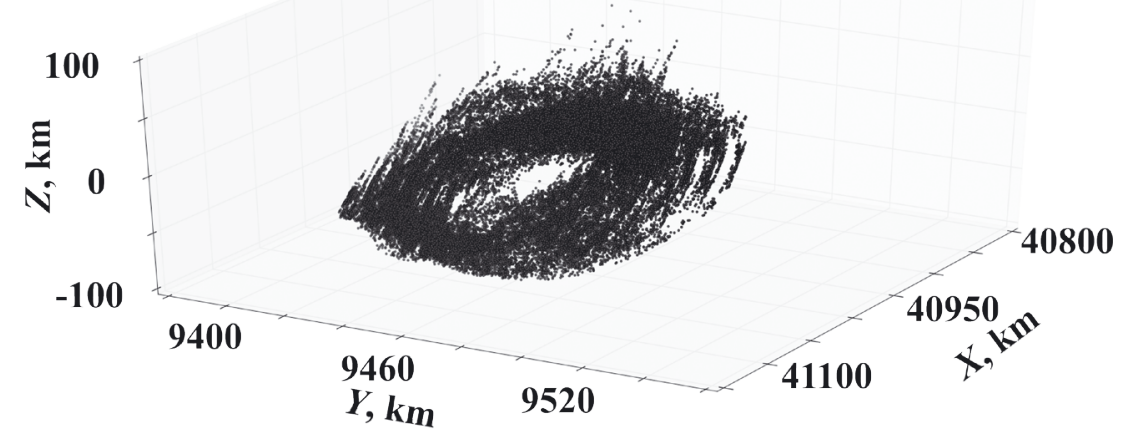

Fig. 4. Spatial positions of Eutelsat-13B satellite in the period of time from 11 March 2015 to 20 May 2015.

The following procedure of discarding of gross errors is used for constructing the graphs shown in Figs. 3 and 4. If corresponding values of $\overline{\Delta r}$ are discarded for at least one of the pairs of stations, averaged values of $\bar{X}, \bar{Y}$ and $\bar{Z}$ are discarded. If the sample size of averaging is less than 10 or the value of the SD of $\Delta r$ exceeds $3.0 \mathrm{~m}$, value of $\overline{\Delta r}$ is discarded.

Empirical probability density and distribution functions of values of standard deviations of $X, Y$ and $Z\left(\sigma_{X}, \sigma_{Y}\right.$ and $\sigma_{Z}$, respectively) are given in Fig. 5. The values of $\sigma_{X}, \sigma_{Y}$ and $\sigma_{Z}$ were computed at 60 -second intervals of time for all samples without discarding gross errors.

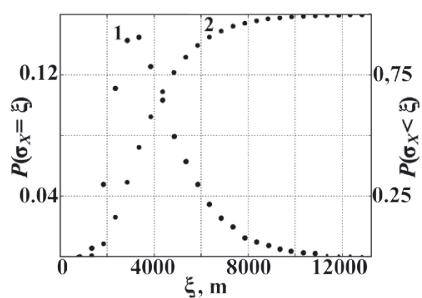

(a)

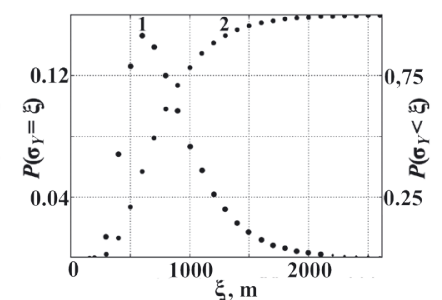

(b)

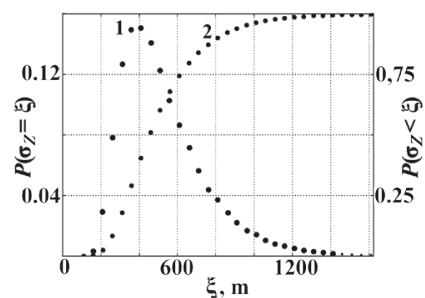

(c)

Fig. 5. Empirical probability density function (1) and distribution function (2) of standard deviation of Cartesian coordinates of Eutelsat-13B satellite in the WGS84: X - (a), Y - (b) and Z - (c).

Due to the data given in Fig. 5, the medians of standard deviations of $X, Y$ and $Z$ are equal to $3540 \mathrm{~m}, 705 \mathrm{~m}$ and $455 \mathrm{~m}$, respectively. Hence, the coordinate $X$ has larger error than $Y$ and $Z$. 


\section{DISCUSSION}

The obtained error (the standard deviation of single measurement) of slant range differences of about $2.6 \mathrm{~m}$ is completely determined by PPS signal accuracy of the ThunderBolt-E GPS receiver [13] and is close to the minimum error for the $\mathrm{RC}$ equipment composition. The minimum error is $7 \mathrm{~ns}$ or $2.1 \mathrm{~m}$. It was obtained in the research [7]. This value is free of the RC synchronization error by the GPS and is mainly caused by the instability of oscillator frequency of the USB-oscilloscopes ADC. Thus, further reduction of the error of $\Delta r$ is possible by increasing the timing accuracy, i.e., the frequency stability of the ADC reference oscillators. For example, the ThunderBolt-E GPS receivers could be replaced with GPS-disciplined rubidium frequency standards [14]. The PPS signal from the rubidium is aligned to UTC and has less than $0.3 \mathrm{~ns}$ jitter. An atomic rubidium oscillator of the GPS10RBN could also be used as the main frequency reference for the ADC. It should be noted that maximum error of slant range difference measurement is caused by the spectral width of the received signal. This error for DVB-S signal with a spectral width of 30 $\mathrm{MHz}$ is less than $1 \mathrm{~ns}$ or $0.3 \mathrm{~m}$. The error was obtained in process [3].

Let $\varepsilon_{a}$ denote the error of an angular coordinate of tracked satellite, and let $B$ be the length of the radio interferometer baseline. In [4], the value of $\varepsilon_{a}$ was equal to about 1 " and it was obtained from the following approximate ratio:

$$
\varepsilon_{a}=\sigma / B
$$

for the radio interferometer with $\sigma=1.2 \mathrm{~mm}$ and $B=250 \mathrm{~m}$. Relation (3) holds at small ratio of $B$ to the distance to the satellite. Let us estimate $\varepsilon_{a}$ for the RC. In this case, the value of $\varepsilon_{a}$ can also be estimated from (3) because the ratio of the minimum distance between the RC stations to the distance to the satellite is significantly less than one (around $10^{-2}$ ). Substituting $\sigma=2.6 \mathrm{~m}$ and $B=400 \mathrm{~km}$ in (3), one finds that $\varepsilon_{a}$ is also approximately equal to 1 ". Thus, the RC value of $\varepsilon_{a}$ coincides with the estimation obtained in [4] due to large length of the RC baseline. Thus, working together with radar, the complex would ensure the same positioning accuracy of the satellite like the radio interferometer considered in [4], [5].

The example above shows that small error value of $\Delta r$ does not guarantee small value of error when determining the coordinates of satellite. It is also necessary that the stations of radio interferometer have been optimally placed in space and at enough large distance from each other. Generally, the error of coordinate determination is nonlinear function of $\sigma$ and $B$ given by the system of equations (1). The nonlinear dependence on $\sigma$ and $B$ of the coordinate errors is confirmed by comparing the accuracy of the Chinese VLBI Network [6] and two versions of the $\mathrm{RC}$. The previous version of the RC (Version 0) differs from the current one (Version 1) in that the Mykolaiv station was synchronized by Resolution-T, which was less accurate than the Thunderbolt-E GPS receiver. Parameters of the radio interferometers (RI) are given in the following table where:

$B_{\mathrm{RI}}$ is the minimum length of baselines of the RI;

$b=\frac{B_{C V N}}{B_{R}}$ is a ratio of values of $B_{\mathrm{RI}}$ for the CVN and RI; 
$\sigma_{\Delta r}$ and $\sigma_{X Y Z}$ are maximum errors for determining of $\Delta r$ and Cartesian coordinates of satellite;

$s=\frac{\left(\sigma_{\Delta r}\right)_{R}}{\left(\sigma_{\Delta r}\right)_{C V N}}$ is a ratio of values of $\sigma_{\Delta r}$ obtained by RI and the CVN;

$v=\frac{\left(\sigma_{X Y Z}\right)_{R}}{\left(\sigma_{X Y Z}\right)_{C V N}}$ is a ratio of values of $\sigma_{X Y Z}$ obtained by RI and the CVN.

Table 1

Comparison of the Accuracy of the CVN and the RC

\begin{tabular}{|l|c|c|c|}
\hline $\mathrm{RI}$ & $B_{\mathrm{RI}}, \mathrm{km} / b$ & $\sigma_{\Delta r}, \mathrm{~m} / s$ & $\sigma_{X Y Z}, \mathrm{~m} / v$ \\
\hline $\mathrm{CVN}$ & $1100 / 1$ & $1 / 1$ & $10 / 1$ \\
\hline $\mathrm{RC}($ Version 0) & $400 / 2.75$ & $4.5 / 4.5$ & $40000 / 4000$ \\
\hline $\mathrm{RC}($ Version 1) & $400 / 2.75$ & $2.6 / 2.6$ & $3540 / 354$ \\
\hline $\mathrm{RC}($ Version 2) & $1000 / 1.1$ & $2.6 / 2.6$ & $\approx 400 / \approx 40$ \\
\hline $\mathrm{RC}($ Version 3) & $1000 / 1.1$ & $0.3 / 0.3$ & $<10 /<1$ \\
\hline
\end{tabular}

The data presented in Table 1 show that the error of slant range difference decreased by 1.7 times after the Resolution-T at the station in Mykolaiv was replaced with a more accurate GPS receiver. At the same time, the error of coordinate determination decreased by more than 10 times. The data also show that the error of coordinate determination by the current version of the RC was two orders of magnitude greater than that for the $\mathrm{CVN}$, while its $\sigma_{\Delta r}$ was 2.6 times greater and its $B_{\mathrm{RI}}$ was less than 2.75 times. It can be concluded that relatively small changes of $\sigma_{\Delta r}$ or $B_{\mathrm{RI}}$ (e.g., doubled) result in significantly greater changes (10 times) of the error of coordinate determination. Taking this into account, the accuracies of two possible versions of the RC (2 and 3) are given in the last two rows of the table. The version 2 differs from the current version of the $\mathrm{RC}$ in that the length of the baseline along latitude is increased by more than twice to $1000 \mathrm{~km}$. It can be expected that the error of coordinate determination will be decreased by about an order of magnitude, up to $400 \mathrm{~m}$. The version 3 differs from the version 2 in that its error of $\Delta r$ estimation is equal to the minimum possible error of $0.3 \mathrm{~m}$. In this case, the error of coordinate determination can be decreased to a value of less than $10 \mathrm{~m}$.

\section{CONCLUSION}

1. The continuous observations of the geostationary telecommunication satellite Eutelsat-13B were performed by the radio engineering complex during more than two months from 11 March 2015 to 20 May 2015. The RC consists of four stations receiving DVB-S signals and spaced at about $1000 \mathrm{~km}$ and $400 \mathrm{~km}$ along longitude and latitude, respectively. 
2. According to these observations, the errors of single measurements of slant range differences and Cartesian coordinates of the tracked satellite were determined. These errors were equal to $2.6 \mathrm{~m}, 3540 \mathrm{~m}, 705 \mathrm{~m}$ and $455 \mathrm{~m}$ for $\Delta r, X, Y$ and $Z$, respectively.

3. The estimations of errors of coordinate determination for possible modifications of the RC were obtained by comparing the accuracy characteristics of two versions of the RC and the CVN. In the case of increasing the minimum baseline of the $\mathrm{RC}$ to the order of $1000 \mathrm{~km}$, the error of coordinate determination can be about 400 $\mathrm{m}$. The estimation of the minimum possible error of geostationary satellite coordinates was also obtained. The error becomes no more than $10 \mathrm{~m}$ in the case of saving the minimum length of the RC baseline equal to about $1000 \mathrm{~km}$, and if slant range difference is estimated with an error equal to or less than $0.3 \mathrm{~m}$.

4. The complex considered can be a prototype of the system of ongoing monitoring of orbits of active geostationary telecommunication satellites. This system can be cheap to implement, fully independent and untied to uplink stations.

\section{REFERENCES}

1. Kara, I.V., Kozyryev, Y.S., Sybiryakova, Y.S., and Shulga, O.V. (2011). NAO catalog of geocentric state vectors of geosynchronous space objects. Bulletin of the Crimean Astrophysical Observatory, 107 (1), 98-102.

2. Montenbruck, O., and Gill, E. (2005). Satellite orbits: Models, methods, and applications. Berlin: Springer.

3. A novel ranging method using DVB-S transport stream packets [online]. Available at http://esamultimedia.esa.int/conferences/01C14/papers/P2.2.pdf.

4. Keeping track of geostationary satellite - A novel and less costly approach [online]. Available at http://www.esa.int/esapub/bulletin/bulletin119/bul119_chap8.pdf.

5. Interferometer for high precision orbit determination [online]. Available at http://adsabs. harvard.edu/full/ 2003ESASP.532E..39P.

6. Huang, Y., Hu, X., Zhang, X., Jiang, D., Guo, R., Wang, H., and Shi, S. (2011). Improvement of orbit determination for geostationary satellites with VLBI tracking. Chinese Science Bulletin, 56 (26), 2765-2772.

7. Bushuev, F.I., Kaliuzhnyi, N.A., Slivinsky, A.P., and Shulga A.V. (2012). Determination of the range to geostationary telecommunications geostationary satellites using the signals of satellite television. Radiofizika i Radioastronomia. 17 (3), 281-290 (in Russian).

8. Multilateration [online]. Available at http://encyclopedia.thefreedictionary.com/multilateration

9. Chernyak, V.S. (1993). Multiposition Radiolocation. Moscow: Radio i Sviaz (in Russian).

10. Hofmann-Wellenhof, B., Lichtenegger, H., and Collins, J. (1995). Global positioning system: Theory and practice. Kyiv: Naukova Dumka (in Ukrainian).

11. European Telecommunications Standards Institute. (1997). Digital video broadcasting (DVB); Framing structure, channel coding and modulation for 11/12 GHz satellite services. European Standard (Telecommunications series). EN 300421 V1.1.2 (1997-08). Sophia Antipolis: ETSI. 
12. Cabot, R. (1981). A note on the application of the Hilbert transform to time delay estimation. IEEE Trans. Acoust. Speech Signal Processing, (29) 3, 607-609. DOI: 10.1109/ TASSP.1981.1163564.

13. Trimble ThunderBolt E GPS Disciplined Clock. User Guide. [online]. Available at http:// www.trimble.com.

14. GPS10RBN: $10 \mathrm{MHz}$, GPS Disciplined, Rubidium Frequency Standard. [online]. Available at http://www.ptsyst.com/GPS10R-B.pdf.

GEOSTACIONĀRA TELEKOMUNIKĀCIJU SATELĪTA POZĪCIJAS

NEPĀRTRAUKTAS MONITORĒ $\bar{S} A N A S$ REZULTĀTI, IZMANTOJOT DIGITĀLĀS SATELİTTELEVİZIJAS SIGNĀLA UZTVERŠANU DAŽĀDOS TELPAS PUNKTOS

\author{
F. Bušujevs, M. Kal̦užnijs, J. Sibirjakova, O. Šuḷga, S. Moskal̦enko, \\ O. Balagura, V1. Kuliš̌enko
}

Kopsavilkums

Rakstā sniegti ǵeostacionārā telekomunikāciju satelīta «Eutelsat-13B» (13º austrumu garums) pozīcijas novērošanas rezultāti. Rezultāti iegūti, izmantojot radioinženierijas kompleksu, kuru veido četras digitālās satelīttelevīzijas signālus uztverošās stacijas Kijevā, Mukačevā, Harkovā un Nikolajevā, kā arī datu apstrādes centrs.

Katras stacijas aprīkojums, izmantojot GPS, l̦auj sinhroni reǵistrēt satelīttelevīzijas DVB-S signāla fragmentus uztvērēja kvadratūras detektora izejā. Kompleksie signāli tika saglabāti un, izmantojot Interneta savienojumu, nosūtīti uz datu apstrādes centru, kur uztverto signālu korelācijas apstrādes rezultātā trīs staciju pāriem tika noteiktas trīs lineāri neatkarīgas tiešā attāluma starpības ( $\Delta r$ ). Izmantojot multilaterācijas metodi, katrā sekundē izmērītās $\Delta \mathrm{r}$ vērtības tika transformētas satelīta Dekarta koordinātēs (XYZ) WGS84 koordinātu sistēmā.

Rakstā analizētas $\Delta \mathrm{r}, X, Y$ un $Z$ laikrindas, kas iegūtas nepārtrauktos novērojumos laikposmā no 2015. gada marta līdz maijam. Viena $\Delta r, X, Y$ un $Z$ mērījuma kḷūda ir atbilstoši 2,6 m, 3540 m, 705 m un 455 m. Izstrādātais komplekss tiek salīdzināts ar zināmiem analogiem. Apskatīti paṇēmieni, kā samazināt satelīta koordināšu noteikšanas kḷūdas.

Kompleksu var uzskatīt par geostacionāro telekomunikāciju satelītu pozīciju neatkarīgas uzraudzības sistēmas prototipu.

24.08.2016. 